\title{
Enhanced growth of black tiger shrimp Penaeus monodon by dietary supplementation with Bacillus (BP11) as a probiotic
}

Ponpisit Utiswannakul' ${ }^{1}$ Siripen Sangchai ${ }^{1}$ and Sirirat Rengpipat ${ }^{1,2 *}$

${ }^{1}$ Department of Microbiology, Bangkok 10330, Thailand

${ }^{2}$ The Center of Excellence for Marine Biotechnology (CEMB), Faculty of Science, Chulalongkorn University, 254 Phayathai Road, Bangkok 10330, Thailand

\begin{abstract}
Bacillus isolate P11 (BP11), isolated from the gastrointestinal tract of the black tiger shrimp, Penaeus monodon, was evaluated for its potential use as a probiotic feed supplement for $P$. monodon culture. BP11, a Gram-positive spore forming bacteria, was identified as a member of the genus Bacillus and most likely to be an isolate of Bacillus subtilis, based on biochemical tests, physical morphology, and 16S rRNA gene fragment sequence analysis. BP11 is likely to be safe as a probiotic for $P$. monodon since no detectable level of antimicrobial substance or Bacillus diarrheal enterotoxin production was found. When the regular feed of $P$. monodon was supplemented with BP11 at $\sim 10^{9} \mathrm{CFU} \mathrm{g}^{-1}$ feed a higher shrimp growth, feed conversion ratio, survival and general health was obtained for both postlarvae $(\mathrm{PL})$ shrimp in concrete tanks and in an earthen pond. In addition, and importantly, the oral administration of BP11 in the shrimp feed led to adherence to the shrimps' intestine surface with BP11 bacteria and an increased immunity to Vibrio harveyi 639 infection, including a reduced mortality. BP11 in dried feed had a reasonable shelf life, with viable cell counts of $\sim 10^{8}$ and $10^{9} \mathrm{CFU} \mathrm{g}{ }^{-1}$ remaining after 6 -months storage at room temperature and $4^{\circ} \mathrm{C}$, respectively.
\end{abstract}

Keywords: Bacillus subtilis; BP11; Penaeus monodon; Black tiger shrimp; Hemocyte count; Antibacterial activity; Vibrio harveyi

\section{Introduction}

Thailand became the world's largest farmed-shrimp exporter in 1994, exporting a total of around $30 \%$ of the world market share [1], and the value of the exported frozen and chilled shrimp from Thailand has remained high $(\sim 2,500$ million per year) during the last ten years (2001-2010) [2]. However, the yield per crop in most black tiger shrimp, Penaeus monodon, farms in Thailand began to seriously decline since 2005 with some complete losses, as seen elsewhere in SE Asia, due to the low quality of brood stocks and outbreaks of viral and bacterial infections. The resulting stunted growth and high mortality rates induced by these infections have led to a change in the major farmed shrimp species in Thailand and elsewhere away from $P$. monodon to the white shrimp, Litopenaeus vannamei, which now accounts for some $90 \%$ of shrimp aquaculture in Thailand and SE Asia [3,4]. Currently, the addition of substantial amounts of antibiotics or chemotherapeutics remains the current method of choice for disease control throughout the shrimp aquaculture industry. However, in addition to the imposed increased costs of such antibiotic administration, and some concern of the health and environmental affects, there is the increasing concern about the predictable spread and increase in antibiotic-resistant bacteria [5-9]. Moreover, it is not clear if the release of virulent pathogen infected aquaculture media back into the sea may lead to transient, but important, mortality in wild shrimp including short term future brood stocks for aquaculture. This has led to alternative suggestions for more sustainable and environmental friendly disease prevention, including the use of non-pathogenic probiotic bacteria [10-13]. This alternative direction of biocontrol aims to make shrimp farming more sustainable. Selection for non-pathogenic probiotic bacteria with a high specificity to the cultured shrimp host and that can provide a healthy balance of indigenous organisms in the hosts' intestines, or other benefits to the host, is the initial starting point of such an approach. However, the degree of regional (population specific) host-probiont-pathogen coevolution is unknown, and so screening of probiotic candidates should include the same brood stock populations as used for the shrimp aquaculture. In addition, the bioactive component(s) or the entire probiotic organism(s), of benefit to the health or safety of commercially farmed shrimp needs to be able to be prepared at commercial scale easily and be relatively stable to at least short-term storage (shelf life) to be of practical applicable use [12,14-20].

Although several probiotics have recently been developed for aquaculture crops, they are still not widely used. There are, however substantial advantages for the use of probiotics in shrimp and fish aquaculture [10,11,21-26]. Among the potential bacterial probiotics for shrimp, some Bacillus spp. have been extensively evaluated as an additive in the feed [22-25,27-29] and in the culture water [30-32]. Several Bacillus spp. naturally constitute a part of the bacterial flora of the intestinal tracts of several marine taxa, including for example B. subtilis in fish [33-35], and B. subtilis and B. pumilus in shrimp [22,25,36]. Concurrently, Bacillus spp. can be isolated from shrimp culture ponds [23-25] and marine environments [37]. Bacillus spp. have rarely been reported as shrimp pathogens, whereas several studies have demonstrated that culturing shrimp with feed supplemented with Bacillus sp. reduced the subsequent mortality induced by vibriosis, in particular, some strains of $V$. harveyi $[12,22,25,27]$. To further study the potential of Bacillus spp. as a probiotic biocontrol agent in shrimp farming, and to sustain commercial black tiger shrimp aquaculture, we isolated Bacillus spp. from the intestines of healthy black tiger shrimp brood stocks derived from the Andaman sea, which is a different area from that previously reported [22]. Thus, this offers the potential of

*Corresponding author: Sirirat Rengpipat, PhD, Department of Microbiology Faculty of Science, Chulalongkorn University, 254 Phayathai Road, Bangkok 10330, Thailand, Tel: 662-2185070, 662-2185089, Fax: 662-2527576; E-mail: sirirat@sc.chula.ac.th

Received July 12, 2011; Accepted October 14, 2011; Published October 24, 2011

Citation: Utiswannakul P, Sangchai S, Rengpipat S (2011) Enhanced growth of black tiger shrimp Penaeus monodon by dietary supplementation with Bacillus (BP11) as a probiotic. J Aquac Res Development S1:006. doi:10.4172/2155-9546. S1-006

Copyright: $(2011$ Utiswannakul P, et al. This is an open-access article distributed under the terms of the Creative Commons Attribution License, which permits unrestricted use, distribution, and reproduction in any medium, provided the original author and source are credited. 
either new Bacillus isolates or those probiotic bacteria that are better adapted to the local shrimp-pathogen isolates of this region. Therefore, the objectives of this research were to isolate potential probiotic Bacillus candidates from the intestines of $P$. monodon from the Andaman sea and to evaluate their effects on the growth, survival and disease resistance of post larva shrimp P. monodon from the same region but reared in concrete tanks and in earthen pond, respectively.

\section{Materials and Methods}

\section{Bacterial strains}

P. monodon brood stocks ( 150-200 g of $\sim 9-12$ inches each) from the Andaman sea along the West coast of Thailand were collected and their intestines were aseptically dissected out. The removed intestine was longitudinally cut and rinsed gently with sterile $0.85 \%$ (w/v) $\mathrm{NaCl}$ (NSS) three times and homogenized. Serial dilutions $\left(10^{-1}\right.$ to $\left.10^{-8}\right)$ in NSS of the intestine homogenate were then plated in triplicate on tryptic soy agar (TSA) plus $1 \%(\mathrm{w} / \mathrm{v}) \mathrm{NaCl}$ plates and cultured at $37^{\circ} \mathrm{C}$ for $24 \mathrm{hr}$, and the number of colonies were counted. Isolated colonies were selected and checked for antibacterial properties against Vibrio harveyi 639 and Escherichia coli ATCC 25922 using an agar diffusion technique, as described in detail by Naclerio et al. [38].

V. harveyi 639 isolated from Penaeus monodon dying of luminescent disease was kindly provided by the Shrimp Culture Research Center, Charoen Pokphan Feedmill, Samutsakorn, Thailand. It was cultured in tryptic soy broth (TSB) or TSA containing $2 \% \mathrm{NaCl}(\mathrm{w} / \mathrm{v})$ at $30^{\circ} \mathrm{C}$ and identity was confirmed as described previously [39], Presumptive

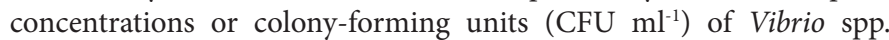
were determined using spread plates of thiosulfate citrate bile sucrose agar (TCBS). Escherichia coli ATCC 25922 was kindly provided from Department of Microbiology, Faculty of Science, Chulalongkorn University. E.coli was cultured on TSA and TSB at $30^{\circ} \mathrm{C}$. All media were obtained from Difco, Sparks, MD, USA.

\section{BP11 identification}

The culture purity and identity of the selected isolate (BP11), which produced the greatest antibacterial performance, was routinely checked during preparation using both conventional methods and the api$20 \mathrm{E}^{\bullet}$ and api-50 $\mathrm{CHB}^{\bullet}$ Medium test kits (BioMérieux, Marcy-I'Etoile, France). The results were analyzed with the APILAB Plus software. Gram staining, spore staining, oxidase and catalase tests were performed following conventional methods and the bacterial morphology was examined as cells / spores under the microscope and as colonies on agar plates. Physiological characteristics were determined in tryptic soy broth (TSB) with various concentrations of $\mathrm{NaCl}(1-4 \%(\mathrm{w} / \mathrm{v}))$ and at different $\mathrm{pH}(6-8)$ and temperatures $\left(35-50^{\circ} \mathrm{C}\right)$.

\section{Determination of the 16S rRNA nucleotide sequence}

Genomic DNA of the selected isolate (BP11) was extracted following the procedure of the Geneclean II kit (Qiagen, Germany), as previously described [40]. The PCR amplification was carried out in a DNA Thermal Cycler (Perkin Elmer, USA) using the universal bacterial 16S rRNA primers: 10F 5' -AGTTTGATCCTGGCTC- 3' and 1540R 5' -AAGGAGGTGATCCAGCC- 3'. PCR reactions were carried in a total volume of $50 \mu \mathrm{l}$, comprised of $\sim 1 \mu \mathrm{g}$ of DNA template, $1 \mu \mathrm{M}$ of each primer, $1.5 \mathrm{mM} \mathrm{Mg}^{2+}, 200 \mu \mathrm{M}$ dNTPs, $1.5 \mathrm{U}$ Taq DNA polymerase in 1 $\mathrm{x}$ Taq DNA polymerase buffer. All PCR reagents were purchased from Promega, USA. The PCR conditions consisted of 35 cycles of $95^{\circ} \mathrm{C}$ for 1 min, $46^{\circ} \mathrm{C}$ for $1 \mathrm{~min}$ and $72^{\circ} \mathrm{C}$ for $1 \mathrm{~min}$, followed by a final $72^{\circ} \mathrm{C}$ for 7 min [41]. After that, the PCR products were sequenced commercially at the BioService Unit (NSTDA, Bangkok, Thailand) using the same F and $\mathrm{R}$ primers for sequencing the leading and lagging strand, as used for the PCR. The consensus sequence was compared with those $16 \mathrm{~S}$ rDNA sequences available in the NCBI GenBank database using the BLASTn search algorithm. The highest sequence identities were aligned using Clustal, checked by eye and used to compute the pair-wise sequence identity and also construct a phylogenic tree using the Neighbor Joining distance method in the PHYLIP Version 3.5. on line software, (http:// evolution.genetics.washington.edu/phylip.html) (June 12, 2010).

\section{Determination of antimicrobial substances}

The evaluation of the production of antimicrobial substances by the BP11 isolate was preliminarily determined using an antimicrobial residue screening test kit (AM-Test), developed by researchers at the Center for Antimicrobial Resistance Monitoring in Food-borne Pathogens (in collaborating with WHO), Faculty of Veterinary Science, Chulalongkorn University, Bangkok, Thailand. The principle is based on the tube diffusion method and the threshold for detection limit for 18 known standard antibiotics which are in the range of $>0.001-0.1$ ppm, depending upon the antibiotic. The BP11 culture broth after a 24 $\mathrm{h}$ (late log phase growth) and $48 \mathrm{~h}$ (spore forming stage) incubation at $30^{\circ} \mathrm{C}$ was harvested by centrifugation (at $6,230 \mathrm{x} \mathrm{g}, 10 \mathrm{~min}$ at $4^{\circ} \mathrm{C}$ ) to pellet the bacteria, and the supernatant passed through a $0.22 \mu \mathrm{m}$ sterile filter and transferred into a tube containing semi-solid agar with spores of the Gram positive Geobacillus stearothermophilus and $\mathrm{pH}$ indicator. Milk containing antibiotic provided in test kit was used as positive control. Tubes were incubated at $65 \pm 1^{\circ} \mathrm{C}$ for $2-2.5 \mathrm{~h}$. During this incubation period any relatively small antimicrobial substances in the sample would diffuse into the agar and inhibit the growth of $G$. stearothermophilus, allowing the purple color to remain, whereas in the absence of any inhibitor a yellow color would be detected.

\section{Determination of the enterotoxin produced by BP11 culture}

Determination of the enterotoxin from filtrates of the BP11cultured broth, were performed following the procedures according to manufacturer's instructions (TECRA ${ }^{\oplus}$ test kit; for the detection of Bacillus diarrheal enterotoxin (BDE); TECRA International Pty Ltd, Frenchs Forest NSW 2086, Australia). The principle of this enterotoxin test is based on the "sandwich" configuration of an enzyme-linked immunosorbent assay (ELISA).

\section{Shrimp feed preparation}

Black tiger shrimp (P. monodon) were fed a commercially formulated feed purchased from Grobest and Phokaphan Aquatech Corporation Co, Ltd., Thailand. The nutrition in feed by weight were as follows: protein $(>35 \%)$, lipid $(>5 \%)$, fiber $(>4 \%)$, moisture $(<10 \%)$, and a trace of ash. For the BP11-supplemented feed, $1 \mathrm{~kg}$ wet weight $(\sim 100 \mathrm{~g}$ dry weight $)$ of BP11 $\left(\sim 10^{-10} \mathrm{CFU} \mathrm{\textrm {g } ^ { - 1 }}\right)$ was thoroughly mixed with $4 \mathrm{~kg}$ of feed (i.e., approximately $2.5 \%(\mathrm{w} / \mathrm{w}) \mathrm{BP} 11$ ). For this purpose, a single $\mathrm{BP} 11$ colony from a TSA plate was cultured in TSB at $30^{\circ} \mathrm{C}$ with shaking at $200 \mathrm{rpm}$ for $24 \mathrm{~h}$ and then harvested by centrifugation at $6,230 \mathrm{x} \mathrm{g}$, $4^{\circ} \mathrm{C}$ for $10 \mathrm{~min}$ and washed three times with NSS before being weighed and re-suspended in fresh NSS. Fresh BP11 cells were then thoroughly mixed with the feed at a 1:4 (BP11: feed), and the mixture was spread out and dried in an oven for $1-2 \mathrm{~h}$ at $37^{\circ} \mathrm{C}$. Feed was then stored in clean plastic bags at $4^{\circ} \mathrm{C}$ until use. Shrimp feed was prepared twice weekly, and each batch was analyzed for the level of viable BP11 cells as CFU ${ }^{-1}$ by the total plate count method. This BP11-supplemented feed typically contained viable BP11 at $\sim 3.9 \times 10^{8}-\sim 3.6 \times 10^{9} \mathrm{CFU} \mathrm{g}^{-1}$. Aliquots from each feed preparation were stored at room temperature $\left(\sim 28-32^{\circ} \mathrm{C}\right)$ and 
at $4^{\circ} \mathrm{C}$ and assayed for viable BP11 levels (as CFU g ${ }^{-1}$ feed) up to six months in order to monitor their survival upon storage.

\section{Experiment I: PL-30 shrimp culture in concrete tanks}

Shrimp age of $\sim$ post larva -15 (PL-15) were purchased from a reputable hatchery at Chachoengsao province in Thailand, and acclimatized to the PL-30 stage $(0.13 \pm 0.01 \mathrm{~g})$ in concrete tanks with flat bottoms (each measuring $80 \times 74 \times 87 \mathrm{~cm}$ ) with a closed recirculating water system of $400 \mathrm{~L}$ [42]. The culture water salinity level was initially set at $20 \%$. These PL-15 shrimp were bred from broodstock caught from the Andaman sea. After acclimatization to the PL-30 stage, healthy active shrimp were randomly assigned into the two groups: a control and probiotic treatment. Shrimp in the control group were fed with shrimp feed (CF), whilst those in the probiotic treatment group were fed with the BP11-supplemented regular shrimp feed (PF). Each treatment was comprised of three replicates, each containing 70 or 60 shrimp/tank for the two trials, respectively. Shrimp were fed three times daily at $10 \%$ body weight and after 90 days of culture the survival (\%) and total live weights $(\mathrm{g})$ were determined.

\section{Experiment II: PL-50 shrimp culture in net cages in earthen pond}

Hatchery reared P. monodon from PL-50 (0.23 $\pm 0.06 \mathrm{~g})$, obtained from the same shrimp hatchery and broodstock as the PL-15 above, were first acclimatized in the cement tank. Shrimp were then preselected for healthy active shrimp and then randomly assigned to the CF- and PF- treatments, as detailed above, and stocked in ten $1.5 \mathrm{~m}^{2}$ net cages $(1.0 \mathrm{~mm}$ mesh $)$ at $100 \mathrm{shrimp} /$ cage. The net cages were all placed at a 1.3 $\mathrm{m}$ water depth in a single $1000 \mathrm{~m}^{2}$ surface area earthen pond (typically $1.5 \mathrm{~m}$ deep) along an access walkway. Cages were suspended $20 \mathrm{~cm}$ above the pond bottom and extended $40 \mathrm{~cm}$ above the water surface. Five cages contained the control (CF) shrimp, while the PF shrimp were housed in the remaining five cages. Individual cages were separated by a distance of approximately $1 \mathrm{~m}$. A row of five cages were separated by a distance $1.5 \mathrm{~m}$ on opposite sides of the walkway for two rows. Two rows of walkways were separated by a distance of one meter. Pond water salinity was $\sim 6-7 \%$ o during the dry season of Thailand and was aerated with a closed-system operation. All shrimp were fed three times daily at $10 \%$ body weight in the net cages for 80 days.

\section{Intestinal microbial investigation of CF- and PF shrimp intestines}

The CF- and PF shrimp of 80 days culture in an earthen pond were randomly selected and kept on ice. Their gastrointestinal tracts were dissected out. The intestines were longitudinally cut and rinsed vigorously with sterile NSS three times before fixation and a portion was fixed in $2.5 \%(\mathrm{w} / \mathrm{v})$ glutaraldehyde in $0.1 \mathrm{M}$ phosphate buffer $\mathrm{pH}$ 7.2 for $2 \mathrm{hr}$. After fixation these samples were then processed following conventional procedures, as reported previously [43], and examined by scanning electron microscopy (SEM) using a Jeol JSM-5410LV (Japan) electron microscope.

Water samples collection: Water samples were collected from the center of each tank $(20 \mathrm{ml})$ and net cage $(200 \mathrm{ml})$ from each treatment for determination of the viable BP11 cells every 15 or 20 days. Water quality measurements included the dissolved oxygen, ammonium, nitrite and phosphate levels plus the temperature, $\mathrm{pH}$ and salinity, and were evaluated as described by Strickland and Parsons [44].

Vibrio harveyi challenge tests: After 90 and 80 days, shrimp cultured in concrete tanks and in an earthen pond, respectively were randomly taken and challenged with Vibrio harveyi 639. The PF- and CF shrimp were subjected to static, disease challenge tests using the

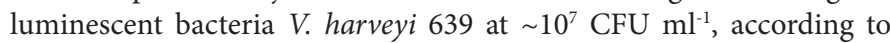
Austin et al. [10] and modified from Rengpipat et al. [22]. Each challenge included 12 tanks with a $2 \times 2$ factorial design. Treatments were the PFand CF shrimp challenged with $V$. harveyi, and unchallenged PF- and CF shrimp. Treatments were performed in triplicate containing 30 and 25 shrimp per tank for shrimp cultured from concrete tanks of Trial I and II, respectively. Triplicate replications of each treatment, using 20 shrimp per tank, for shrimp cultured from the net cages in an earthen pond.

During V. harveyi challenge tests, no water was exchanged and the water quality parameters and shrimp survival were measured every $2 \mathrm{~d}$. The cumulative number of dead shrimp was recorded each day. Shrimp that died following $V$. harveyi 639 exposure were dissected and the hepatopancreas-intestine and heart muscle were removed, cut and fixed in Davidson's fixative solution for $24 \mathrm{~h}$ and then processed for paraffin sectioning by standard techniques. Tissue sections ( $8 \mu \mathrm{m}$ thick) were prepared and processed for haematoxylin and eosin staining $(\mathrm{H}$ \& E) followed by indirect immunoperoxidase staining using first the anti-Vibrio VH3-3H murine monoclonal antibody [45] and secondly the horseradish peroxidase conjugated goat-anti-mouse (GAM-HRP) secondary antibody, diluted to $1: 1000$ in $10 \%(\mathrm{v} / \mathrm{v})$ normal calf serum in PBS, as reported previously [45]. A positive immunoreactivity was visualized as a deep brown coloration against the pink and purple background of the $\mathrm{H} \& \mathrm{E}$ staining. In addition, the bacteria isolated from the hepatopancreas-intestine and heart muscle of each shrimp, were purified and identified using Gram staining, oxidase and motility tests as described previously [39], and were compared with the original $V$. harveyi 639 culture to confirm the similarity to the $V$. harveyi strain.

Haemolymph collection: For determination of the total haemocyte count and antibacterial activity before and after challenge with $V$. harveyi, the haemolymph from shrimp that were cultured in the net cages in the earthen pond was collected from the ventral-sinus cavity of each shrimp using a 26-gauge needle and a 1-ml syringe containing modified KC-199 medium (K-199 medium plus Hepes $2.38 \mathrm{~g} \mathrm{l}^{-1}$, supplemented with 5\% (w/v) L-cysteine as an anticoagulant [46]).

Total haemocyte count: A $100 \mu$ aliquot of the haemolymph, collected from three randomly selected shrimp per tank, was diluted into $0.4 \mathrm{ml}$ of modified KC-199 medium and mixed gently, and then the haemocytes were counted using a haemocytometer under a light microscope at $400 \mathrm{x}$ magnification, and calculated as cells $\mathrm{ml}^{-1}$ of haemolymph.

Antibacterial activity: One hundred microlitre of the shrimp haemolymph was added to $1.4 \mathrm{ml}$ of ice cold, sterile Van Harrevald's salt solution (VHS) [47], mixed and then centrifuged at 600x $\mathrm{g}$ for 10 min at $4^{\circ} \mathrm{C}$. The plasma supernatant was collected and sterilized by filtration (millipore membrane filter, $0.45 \mu \mathrm{m}$ pore size) for subsequent assays for antibacterial activity. $V$. harveyi 639 was cultured in TSB supplemented with $2 \%(\mathrm{w} / \mathrm{v}) \mathrm{NaCl}$ overnight at $37^{\circ} \mathrm{C}$. The concentration was adjusted to $\sim 10^{4} \mathrm{CFU} \mathrm{ml}{ }^{-1}$, collected and washed in $2 \%(\mathrm{w} / \mathrm{v})$ NSS by centrifugation at $92,006 \mathrm{x}$ g for $15 \mathrm{~min}$ at $4^{\circ} \mathrm{C}$. The $V$. harveyi 639 suspension and shrimp plasma (100 $\mu \mathrm{l}$ each) were mixed in a sterile test tube and incubated for $1 \mathrm{hr}$ at $37^{\circ} \mathrm{C}$. Three $50 \mu \mathrm{l}$ aliquots were taken from each tube and spread on thiosulfate-citrate-bile-sucrose (TCBS) agar plates to estimate the viable bacterial numbers as CFU $\mathrm{ml}^{-1}$ after incubating at $37^{\circ} \mathrm{C}$ for $24 \mathrm{hr}$. For the positive control, $V$. harveyi 639 were incubated with VHS. The percentage inhibition was calculated as 
Citation: Utiswannakul P, Sangchai S, Rengpipat S (2011) Enhanced growth of black tiger shrimp Penaeus monodon by dietary supplementation with Bacillus (BP11) as a probiotic. J Aquac Res Development S1:006. doi:10.4172/2155-9546.S1-006

reported elsewhere [48], where; \%inhibition $=100-\left(\right.$ mean CFU ml ${ }^{-1}$ sample/mean CFU ml-1 positive control) $\times 100$

Statistical analysis: The effect of BP11 on the shrimp growth and survival were evaluated using student's t-test [49] with $\mathrm{p}<0.05$ as the confidence level for significant differences. Completely randomized design was carried out to determine for immune indices and disease resistance after shrimp challenged by V. harveyi 639 .

\section{Results}

\section{BP11 identification and its characteristics}

Of the 245 bacterial isolates obtained from screening the intestines of freshly caught $P$. monodon broodstocks from the Andaman sea, BP11 isolate produced the greatest antimicrobial activity against $V$. harveyi 639 and E. coli (data not shown), and so was selected for further evaluation.

BP11, a Gram-positive rod bacteria with a cell size of $\sim 0.55-0.75 \mathrm{x}$ 2.5-3.5 $\mu \mathrm{m}$ (width $\mathrm{x}$ length), can form a central spore (Figure 1), and gave good growth in TSB containing $1-4 \%(\mathrm{w} / \mathrm{v}) \mathrm{NaCl}$; at temperature of $35-50^{\circ} \mathrm{C}$ and $\mathrm{pH}$ of $6-8$. The best growth was found in TSB with $2 \%$ (w/v) $\mathrm{NaCl}$ at $45^{\circ} \mathrm{C}$ and a $\mathrm{pH}$ of 6.5 (data not shown). The BP11 isolate

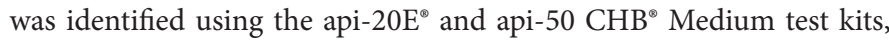
where, after analysis with the APILAB Plus software, the percentage similarity of BP11 to Bacillus subtilis was found to be $99.9 \%$. Moreover, sequence analysis of the $1491 \mathrm{bp}$ partial $16 \mathrm{~S}$ rRNA gene fragment from BP11 (GenBank accession code HM585370) exhibited the highest sequence identity to those sequences annotated as B. subtilis or $B$. amyloliquefaciens ( $>99 \%$ sequence identity), supported by a NJ distance based phylogenetic tree which grouped BP11 within the B. subtilis/B. amyloliquefaciens clade (data not shown). Thus, the biochemical and morphological analysis combined with the $16 \mathrm{~S}$ r-RNA based molecular analysis place BP11 as a potential isolate of B. subtilis within the Firmicutes bacterial division.

\section{Antimicrobial and enterotoxin detection}

In contrast to the positive control (milk containing antibiotics) that showed a purple color, a yellow color was detected in the AM-test for filtrates of BP11 broth. Thus, no antimicrobial residue was detected in the BP11 broth after 24 and $48 \mathrm{hr}$ of culture. In addition no BDE was detected in the BP11 broth culture by the TECRA test kit.

\section{PL-30 and PL-50 shrimp culture in concrete tanks and in earthen pond}

Water quality: The water quality values, during the two experiments each, for the shrimp cultures in the concrete tanks and in the earthen pond were similar for dissolved oxygen $(\sim 10$ and 6.1-7.7 $\left.\mathrm{mg} \mathrm{l}^{-1}\right)$, ammonium $\left(0.0-0.5\right.$ and $\left.0.0 \mathrm{mg}^{-1}\right)$, nitrite $(0.0-0.5$ and $0.1 \mathrm{mg}$ $\left.\mathrm{l}^{-1}\right)$ and phosphate $\left(0.1-0.2\right.$ and $\left.<0.1-0.25 \mathrm{mg} \mathrm{l}^{-1}\right)$, but slightly different for the $\mathrm{pH}\left(6.5-7.0\right.$ and 7.7-8.4), temperature $\left(26-27\right.$ and $\left.28.4-31.4^{\circ} \mathrm{C}\right)$ and salinity (20-23 and 6.1-7.2\%). However, all of these water quality parameters were considered safe for shrimp culture [42,50,51]. BP11 counts of $\sim 10^{2}-10^{3} \mathrm{CFU} \mathrm{ml}{ }^{-1}$ were found in all culture water taken from the concrete tanks or net cages of shrimp fed with BP11-supplemented feed (data not shown).

\section{Experiment I: PL-30 Shrimp growth in concrete tanks}

The average live weights of the CF shrimp in the concrete tanks after 90 days of culture for the two separate trials $(6.17 \pm 0.61 \mathrm{~g}$ and $6.99 \pm 0.19 \mathrm{~g})$ were significant different $(p<0.05)$ from those of the PF shrimp $(7.48 \pm 0.23 \mathrm{~g}$ and $8.94 \pm 0.43 \mathrm{~g})$ (Table 1$)$.

\section{Experiment II: PL-50 shrimp growth in the net cages in the earthen pond}

The influence of BP11 on PL-50 shrimp growth and survival over 80 days was evaluated by simulating to a certain extent the conditions used in commercial shrimp culture using $1.5 \mathrm{~m}^{2}$ surface area net cages, located in a $1,000 \mathrm{~m}^{2}$ surface area earthen pond. The average live weights of the PF shrimp $(13.74 \pm 0.77 \mathrm{~g})$ in the net cages after 80 days culture were significantly different from that of the CF shrimp $(12.86 \pm 0.38 \mathrm{~g})$ (Table 2). In addition, the survival of PF-group shrimp (76.77 $\pm 3.78 \%$ ) was higher than that in the CF shrimp (65.2 \pm 7.60$)$ (Table 2). The food conversion ratio and productive index in the PF-group shrimp were better than those in the CF shrimp (Table 2).

\section{Intestinal microbial investigation of CF- and PF shrimp intestines}

After culture for 80 days in the earthen pond, both the CF- and PF shrimp were randomly selected. The intestines were dissected out for sample preparation and examination by SEM to detect adherent bacteria on the intestinal wall. No bacteria conforming to the morphology of the BP11 was detected on the surface of the intestine of the CF shrimp
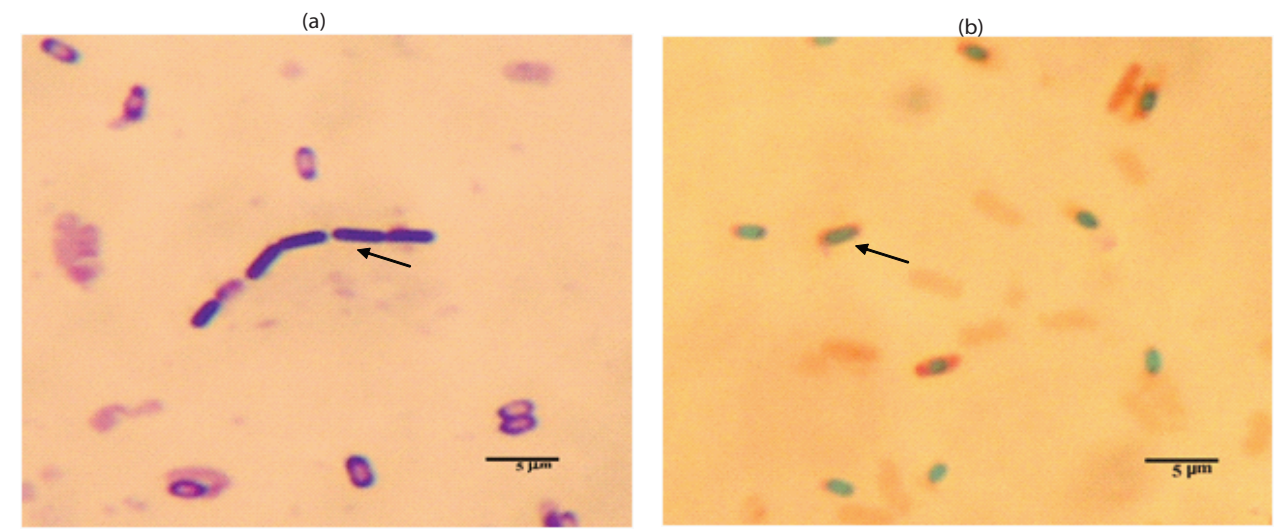

Figure 1: Light microscope images (x 1,000 magnification) of the Gram-positive rods and spores of BP11. (a) The cells, sized $\sim 0.55-0.75 \times 2.5-3.5 \mu$ m (width $x$ length) and (b) the central spore of BP11 as pointed by arrow. 
Citation: Utiswannakul P, Sangchai S, Rengpipat S (2011) Enhanced growth of black tiger shrimp Penaeus monodon by dietary supplementation with Bacillus (BP11) as a probiotic. J Aquac Res Development S1:006. doi:10.4172/2155-9546.S1-006

Page 5 of 9

\begin{tabular}{|c|c|c|}
\hline Experiment I & Control (CF) & Probiotic (PF) \\
\hline \multicolumn{3}{|l|}{ Trial I $(\mathrm{n}=210)$} \\
\hline Average daily gain (mg) & 68.1 & $\begin{array}{l}1.46 \\
82.6\end{array}$ \\
\hline Survive & 67.14 & 84.29 \\
\hline \multicolumn{3}{|l|}{ After challenge by $V$. harveyi: } \\
\hline Cumulative mortality (\%) on day 4 & $55.0 \pm 5.29$ & $28.33 \pm 3.06^{*}$ \\
\hline \multicolumn{3}{|l|}{ Trial II $(\mathrm{n}=180)$} \\
\hline $\begin{array}{l}\text { Average individual live weight }(\mathrm{g}) \text { on day } 90 \\
\text { culture }(\mathrm{n}=30)\end{array}$ & & \\
\hline Average daily gain (mg) & & $.74^{*}$ \\
\hline Survival (\%) & $61.11 \pm 2.48$ & $63.89 \pm 1.47$ \\
\hline \multicolumn{3}{|l|}{ After challenge by $V$. harveyi: } \\
\hline Cum & $56.0 \pm$ & 17.7 \\
\hline Cumulative mortality (\%) on day 9 & 100 & $44.0 \pm 3.53^{*}$ \\
\hline
\end{tabular}

*Indicates a significant difference $(p<0.05)$ between the control $(C F)$ and probiotic (PF) treatment groups.

Average daily gain; Total weight per days of culture

Table 1: Survival and average live weight of shrimp after 90 days culture in concrete tanks fed with (PF) or without (CF) BP11 supplemented feed, and their cumulative mortality after challenge by Vibrio harveyi 639 .

\begin{tabular}{lll}
\hline Parameters & Control(CF) & Probiotic(PF) \\
\hline Total live weight $(\mathrm{kg})$ & 4.56 & 5.33 \\
$\begin{array}{l}\text { Average individual live weight }(\mathrm{g}) \text { on day } 80 \text { of the } \\
\text { culture }(\mathrm{n}=100)\end{array}$ & $12.86 \pm 0.38$ & $13.74 \pm 0.77^{*}$ \\
$\mathrm{FCR}^{(1)}$ & 2.02 & 1.78 \\
Survival $(\%)$ & $65.2 \pm 7.6$ & $76.8 \pm 3.78$ \\
$\mathrm{Pl}^{(2)}$ & 184 & 287.5 \\
\hline
\end{tabular}

${ }^{*}$ Indicates a significant difference $(p<0.05)$ between the control $(C F)$ and probiotic (PF) shrimp

(1)Food conversion ratio; dried weight of ingested feed per live weight of produced shrimp

(2) Productive index; Shrimp weight $x \%$ survival $x 100$ per FCR x age

Table 2: Survival and total live weight of shrimp after 80 days of culture in net cages in an earthen pond fed with (PF) or without (CF) BP11 probiotic supplement in the feed (Experiment II).
(Figure 2a and b), whereas many rod-shaped bacteria were observed on certain surface area of some intestine portions from PF shrimp (Figure $2 \mathrm{c}$ and $\mathrm{d}$ ). Concurrently, BP11 counts from the total bacteria counts $\left(\sim 10^{6}-10^{7} \mathrm{CFU} \mathrm{g}{ }^{-1}\right.$ intestine of either CF-or PF shrimp, data not shown) were $<10^{1}-10^{2}$ and $\sim 10^{5}-10^{6} \mathrm{CFU} \mathrm{g} \mathrm{g}^{-1}$ intestine for the CF- and PF shrimp, respectively (data not shown), which supports the possible presence of BP11 on the surface of the PF shrimp's intestines.

\section{Longevity of BP11 in dried feed}

Viable BP11 counts in the BP11 supplemented feed were found to be $\sim 10^{9}$ and $\sim 10^{8} \mathrm{CFU} \mathrm{g}{ }^{-1}$ of feed after storage for 6 months at $4^{\circ} \mathrm{C}$ and room temperature $\left(28-32^{\circ} \mathrm{C}\right)$, respectively. No changes in the physical morphology or the biochemical properties of BP11 were detected upon storage at either temperature for 6 months. Moreover, a clear probiotic affect of BP11, including the growth and vibriosis resistance enhancement in P. monodon (in vivo), was evident after storage at $-18^{\circ} \mathrm{C}$ for 2 years, where for example the data of Table 2 is derived from the use of a 2 year old storage culture of BP11,

\section{V. harveyi challenge test}

The shrimp cultured in the concrete tanks for 90 days were collected and tested for disease resistance to a $V$. harveyi challenge by external exposure. It was found that the cumulative shrimp mortality was significantly lower in the PF shrimp than in the CF shrimp after external challenge with $V$. harveyi 639 for 4 or 5 days. After 9 days, $100 \%$ cumulative mortality was found in the CF shrimp compared to only $44 \%$ for the PF shrimp (Table 1 ). Thus, the BP11 supplemented feed appeared to afford (prophylactic) protection to the P. monodon shrimp against $V$. harveyi 639 induced mortality.

Likewise, when PL-50 shrimp collected from the net cage culture after 80 days in the earthen pond were challenged by V. harveyi 639
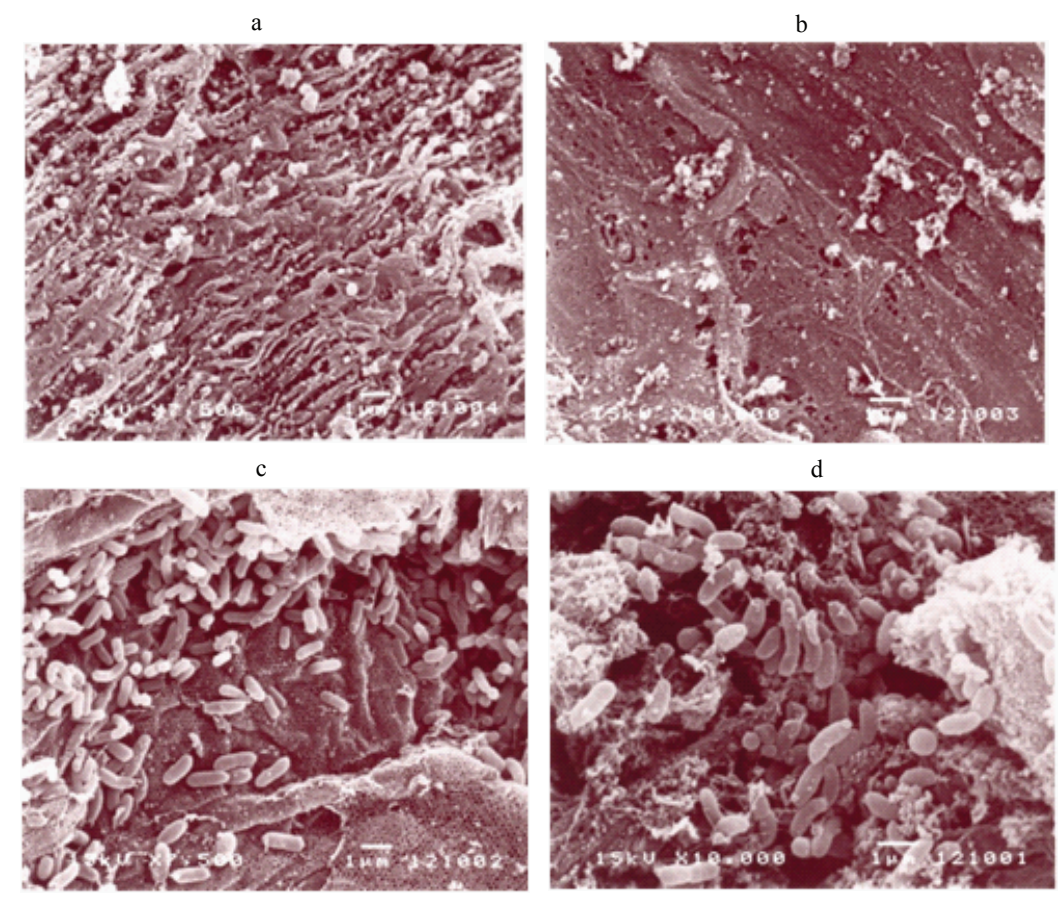

Figure 2: Representative SEM images of intestinal bacteria of 80-day earthen pond cultured shrimps' intestines (a, b) without (CF) or (c, d) with BP11 supplementation and shown at $(a, c) \times 7,500$ or $(b, d) \times 10,000$ magnification. 
Citation: Utiswannakul P, Sangchai S, Rengpipat S (2011) Enhanced growth of black tiger shrimp Penaeus monodon by dietary supplementation with Bacillus (BP11) as a probiotic. J Aquac Res Development S1:006. doi:10.4172/2155-9546.S1-006

Page 6 of 9

\begin{tabular}{|c|c|c|c|c|}
\hline \multirow{2}{*}{ Parameters } & \multicolumn{2}{|c|}{ Before $V$. harveyi challenge } & \multicolumn{2}{|c|}{ After V. harveyi challenge } \\
\hline & Control (CF) & Probiotic (PF) & Control (CF) & Probiotic (PF) \\
\hline Total haemocytes $\left(\times 10^{7}\right.$ cells $\left.\mathrm{ml}^{-1}\right)$ & $1.32 \pm 0.69$ & $1.62 \pm 0.19$ & $0.35 \pm 0.24$ & $0.11 \pm 0.10$ \\
\hline Antibacterial activities (\% inhibition) & $17.3 \pm 4.0^{\mathrm{a}}$ & $39.0 \pm 3.9^{b}$ & $63.7 \pm 8.1^{c}$ & $71.1 \pm 5.6^{c}$ \\
\hline Cumulative mortality (\%); day 5 & _ & _ & $81.7 \pm 16.1$ & $67.7 \pm 10.4$ \\
\hline
\end{tabular}

Data are shown as the mean $+1 \mathrm{SD}$, and are derived from nine shrimp per treatment. Means within a row followed by a different superscript letter are significantly different $(\mathrm{p}<0.05)$.

Table 3: Mean immunity indices values and cumulative mortality (\%) of shrimp fed with (PF) or without (CF) BP11 supplement in the feed in net-cage culture in an earthen pond, before and after challenge with Vibrio harveyi 639 for 5 days.

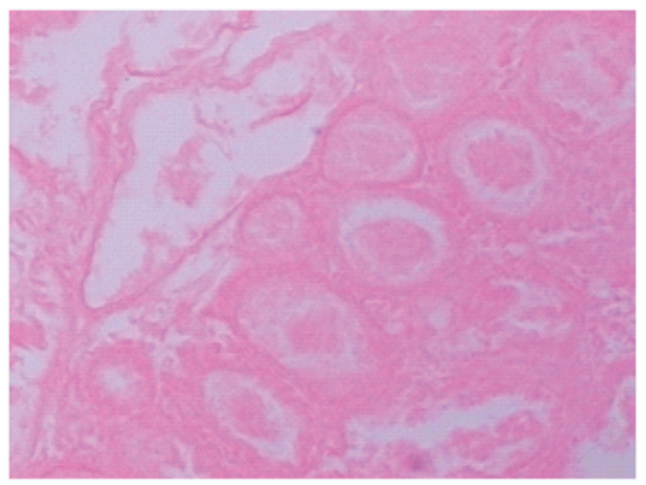

c

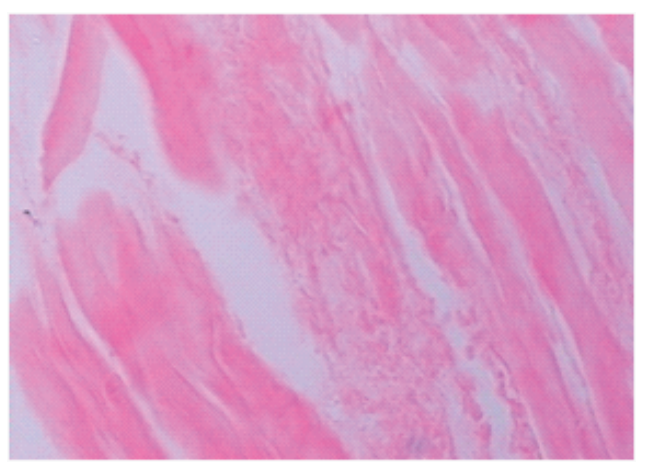

b

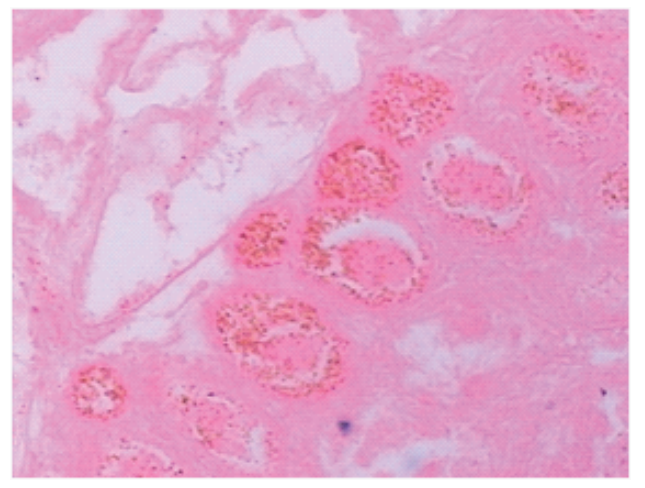

d

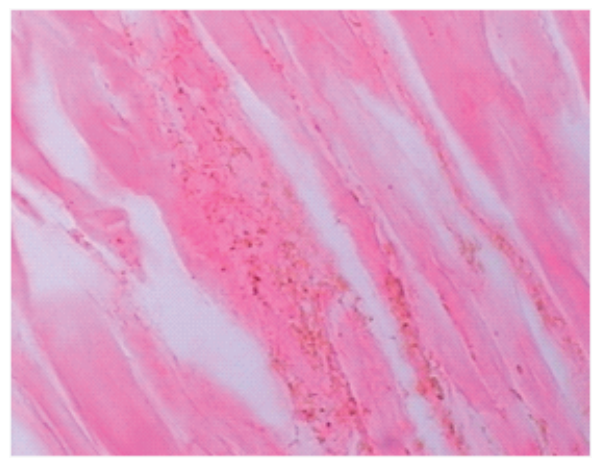

Figure 3: Representative immunohistochemical detection of $V$. harveyi infected tissues from dead $P$. monodon following exposure to $V$. harveyi 639 . The (a,b) hepatopancreas and $(c, d)$ heart muscle after staining by haematoxylin and eosin( $\mathrm{H} \& \mathrm{E})$ while the right panels (b,d) in each case were also stained with indirect immunoperoxidase using the $\mathrm{VH} 3-3 \mathrm{H}$ monoclonal antibody as a probe. Thus, brown dots show the presence of $\mathrm{V}$. harveyi 693 . Images shown are representative from three independent shrimp and examined under light microscope (x 1,000 magnification).

for 5 days, significantly lower cumulative mortality was observed in the PF shrimp than in the CF shrimp (Table 3). Survival was $100 \%$ in unchallenged control shrimp.

Those PL-30 and PL-50 shrimp from the concrete tanks and earthen pond, respectively, that had died after exposure to $V$. harveyi 639 were checked for evidence of internal $V$. harveyi infection by immunohistochemistry of the hepatopancreas-intestines and muscle tissues using the $V$. harveyi 639 specific $\mathrm{VH} 3-3 \mathrm{H}$ monoclonal antibody (Figure 3), and by standard microbiological examination ( $V$. harveyi counts were $\sim 10^{5}-10^{6} \mathrm{CFU}$ g intestine, data not shown). In all cases $V$. harveyi infection was detected in the examined internal tissues. No shrimp mortality was detected among unchallenged CF-and PF shrimp.

Immunity indices: Only the PL-50 shrimp from the net cages in the earthen pond were collected for monitoring their immunity indices during the $V$. harveyi challenge test over 5 days. Before $V$. harveyi challenge the total haemocyte level and the antibacterial activity, from the PF shrimp were numerically greater than those of the CF shrimp
(Table 3), although only the antibacterial activity was significantly different between the two groups. After $V$. harveyi challenge both the CF- and PF shrimp significantly increased their antibacterial activities and decreased the number of circulating haemocytes, but a significantly greater increase in the antibacterial activity upon $V$. harveyi challenge was noted for the PF shrimp. Also, the total circulating haemocyte numbers of the PF shrimp were lower than those of the CF shrimp.

\section{Discussion}

BP11 is one of the natural bacterial flora found in the intestines of black tiger shrimp from the Andaman sea off the Thai coast and was found not to produce any detectable amount of antimicrobial substances or BDE in TSB based liquid culture. BP11 was identified as being a member of the genus Bacillus and most likely as an isolate of $B$. subtilis, which is not known as a human or animal pathogen, nor is it toxigenic like some other members of this genus [52]. B. subtilis has also been authorized in the list of additives for feeding stuffs published by 
the European Union Commission [53]. BP11 was preliminarily selected as a probiotic candidate after its inhibitory effect on Vibrio harveyi 639 growth had been detected in vitro (data not shown). BP11 level in freshly dried feed $\sim 10^{8}$ and $10^{9} \mathrm{CFU} \mathrm{g}{ }^{-1}$ was still found after storage for 6 months at room temperature and $4^{\circ} \mathrm{C}$, respectively, showing that $\mathrm{BP} 11$ is fairly stable in accord with the fact that Bacillus species can resist extreme environments and can produce spores, as can be seen for the BP11 isolate (Figure 1b). This affords them a greater survival, including a longer shelf life in feed, than other groups of bacteria during storage [54]. In addition, after storage at $-18^{\circ} \mathrm{C}$ for 2 years, BP11 was found to still be able to cause growth enhancement in P. monodon (in vivo), as shown in Table 2, supporting the efficacy of BP 11 to induce beneficial effects to hosts, to be able to retain their probiotic properties after feed processing, and to display a sufficient bacterial survival level during storage. These are all important properties for consideration as a good probiotic, as suggested previously $[55,56]$.

More than 15 years after the first finding of Bacillus S11 (BS11) as a potential probiotic for black tiger shrimp [22], we here isolated Bacillus P11. Although both BS11 and PP11 have been identified as isolates of Bacillus subtilis, their cell size, physical appearance of their colonies on agar plates and the optimal growth conditions of BS11 and BP11 are different, suggesting they are different strains. It is thus unclear if this represents stable probiotic-shrimp relationships between different host populations or a change over time due to environmental changes.

After 80 days of being fed BP11 supplemented feed (PF shrimp) in an earthen pond, BP11 bacterial counts in the shrimp intestines were found to be $\sim 10^{5}-10^{6} \mathrm{CFU} \mathrm{g}{ }^{-1}$ of shrimp intestines, and likely BP11 (cells conforming to Bacillus BP11 morphology) were found on the intestine's surface by SEM analysis (Figure $2 c$ and d). Meanwhile, very rare detection of bacteria on the intestines of the CF shrimp (fed with regular feed) was observed by SEM analysis (Figure 2a and b), though total bacteria counts $\sim 10^{6}-10^{7} \mathrm{CFU} \mathrm{g}{ }^{-1}$ intestine of either CF-or PF shrimp were determined (data not shown). This finding supports the ability of BP11 to adhere to the mucosal surface of the shrimp's intestines more than other bacterial flora (Figure 2), which supports our previous finding of BS11 on shrimp intestines' surface using Green fluorescent protein (GFP) as a monitoring system [57]. The benefits of probiotics to the host have been reported as providing an interfering substance to inhibit pathogens, produce useful enzymes or increase the uptake of useful nutrients, provide a competitive exclusion effect on pathogens and help beneficial immune induction [23,25,27,58-60]. In our case, using the principle of balancing an indigenous microorganism in situ along the intestinal tract, BP11 may possibly function as a protective barrier against pathogens, perhaps by competitive exclusion preventing pathogens like $V$. harveyi from gaining occupation and becoming a major member of the intestinal flora as mentioned earlier [12,14-17, $19,20,25,61]$. However, they may also produce enzymes to digest and absorb nutrients and thus lead to healthy shrimp. That BP11 adhered to the surface of the shrimp intestinal wall better than other bacterial flora may due to specific interaction (recognition) between the shrimp host and probiotic bacteria. All the above beneficial effects of probiotic bacteria on the shrimp are not mutually exclusive and could occur simultaneously. In addition, the lysis of the probiotic bacteria could release peptidoglycan, an immunogen that can induce the immune responses of the shrimp, as suggested previously [62-65].

The yield of probiotic fed shrimp (PF group) in the concrete tanks were significantly higher than those of the control shrimp (CF group). However, before BP11 can be recommended for use in commercial farms, confirmation was sought by evaluation of its effects in net caged shrimp in an earthen pond that more closely simulates an actual commercial culture environment. Our results still confirmed the same positive outcome of shrimp fed BP11, including the prophylactic response towards protection from vibriosis. In addition, $B$. subtilis is known to be a non- to low- virulent species and requires a high number of bacteria to cause disease in humans [66]. Therefore, in conclusion, BP11 could be a good probiotic candidate for black tiger shrimp, P. monodon, as an alternative to antibiotics or chemical agents, and may lead to a more sustainable and safe commercial shrimp culture. However, regarding the recognition as safe for human consumption, risk assessment of BP11 should be further confirmed.

\section{Acknowledgements}

The authors sincerely thank Robert Butcher for revising the manuscript and providing many valuable suggestions and comments. This research was supported by the Thai Government Stimulus Package 2 (TKK 2555) under the Project for Establishment of Comprehensive Center for Innovative food, Health products and Agriculture (PERFECTRA); the Higher Education Research Promotion and National Research University Project of Thailand, Office of the Higher Education Commission (FW643A); CU Graduate School Thesis Grant from Chulalongkorn University and the National Research Council of Thailand (NRCT).

\section{References}

1. Pongthanapanich $T$, Roth $E$ (2006) Toward environmental responsibility of Tha shrimp farming through a voluntary management scheme. IME Working paper 70/06. Department of Environment and Business Economics. University of Southern Denmark, Esbjerg and the authors. 1-44.

2. Fisheries statistics of Thailand (2001-2010). Part 5: Foreign trade of fishery community. Annual report of Information Technology Center, Department of Fisheries, Ministry of Agriculture and Cooperatives, Thailand.

3. Lebel L, Lebel P, Garden P, Giap DH, Khrutmuang S, et al. (2008) Places chains, and plates: Governing transitions in the shrimp aquaculture productionconsumption system. Globalizations 5: 211-226.

4. Lebel L, Mungkung R,Gheewala HS, Leel P (2010) Innovation cycles, niches and sustainability in the shrimp aquaculture industry in Thailand. Environ Sc Policy. 13: 291-302.

5. Amábile-Cuevas CF, Gárdenas-Garciá M, Ludgar M (1995) Antibiotic resistance. Am Sci 83: 320-329.

6. Karunasagar I, Pai R, Malathi GR, Karunasagar I (1994) Mass mortality of Penaeus monodon larvae due to antibiotic resistant Vibrio harveyi infection. Aquaculture 128: 203-209.

7. Holmström K, Gräslund S, Wahström A, Poungshompoo, S, Bengtsson BE, et al. (2003) Antibiotic use in shrimp farming and implications for environmental impacts and human health. Int J Food Sci Technol 38: 255-266.

8. Le TX, Munekage Y, Kato SI (2005) Antibiotic resistance in bacteria from shrimp farming in mangrove areas. Sci Total Environ 349: 95-105.

9. Tendencia EA, de la Peña LD (2001) Antibiotic resistance of bacteria from shrimp ponds. Aquaculture 195: 193-204.

10. Austin B, Stuckey LF, Robertson PAW, Effendi I, Griffith DRW (1995) A probiotic strain of Vibrio alginolyticus effective in reducing diseases caused by Aeromonas salmonicida, Vibrio anguillarum and Vibrio ordalii. J Fish Dis 18: 93-96.

11. Bly JE, Quiniou SM-A, Lawson LA, Clem LW (1997) Inhibition of Saprolegnia pathogenic for fish by Pseudomonas fluorescens. J Fish Dis 20: 35-40.

12. Verschuere L, Rombaut G, Sorgeloos P, Verstraete W (2000) Probiotic Bacteria as Biological Control Agents in Aquaculture. Microbiol Mol Biol Rev 64: 655-671.

13. Westerdahl A, Olsson JC, Kjelleberg S, Conway PL (1991) Isolation and characterization of turbot (Scophthalmus maximus)-associated bacteria with inhibitory effects against Vibrio anguillarum. Appl Environ Microbiol 57: 2223-2228

14. Fuller R (1989) A Review: Probiotics in Man and Animals. J Appl Bacteriol 66 365-378.

15. Fuller R (1992) Probiotics: The Scientific Basis, 1st edn. Chapman\&Hall, London. 
Citation: Utiswannakul P, Sangchai S, Rengpipat S (2011) Enhanced growth of black tiger shrimp Penaeus monodon by dietary supplementation with Bacillus (BP11) as a probiotic. J Aquac Res Development S1:006. doi:10.4172/2155-9546.S1-006

16. Fuller R (1997) Probiotics 2: Applications and Practical Aspects 1st edn. Chapman \& Hall, London.

17. Gatesoupe FJ (1999) The use of probiotics in aquaculture. Aquaculture 180: 147-165

18. Tannock GW (1999) Introduction. In: Probiotics: A Critical Review (ed. by G. W. Tannock) pp. 1-4. Horizon Scientific Press, Norfolk, England

19. Irianto A, Austin B (2002) Use of probiotics to control furunculosis in rainbow trout, Oncorhynchus mykiss (Walbaum) J Fish Dis 25: 333-342.

20. Kesarcodi-Watson A, Kaspar H, Lategan MJ, Gibson L (2008) Probiotics in aquaculture: The need, principles and mechanisms of action and screening processes. Aquaculture 274: 1-14.

21. Gildberg A, Mikkelsen H, Sandaker E, Ringø E (1997) Probiotic effect of lactic acid bacteria in the feed on growth and survival of fry and Atlantic cod (Gadus morhua). Hydrobiologia 352: 279-285.

22. Rengpipat S, Phianphak W, Piyatiratitivorakul S, Menasveta P (1998) Effect of probiotics on Black tiger shrimp Penaeus monodon survival and growth. Aquaculture 167: 301-313.

23. Vaseeharan B, Ramasamy P (2003) Control of pathogenic Vibrio spp. by Bacillus subtilis BT23, a possible probiotic treatment for black tiger shrimp Penaeus monodon. Lett Appl Microbiol 36: 83-87.

24. Li P, Burr GS, Gatlin DM, Hume ME, Patnaik S, et al. (2007) Dietary supplementation of short-chain fructooligosaccharides influences gastrointestina microbiota composition and immunity characteristics of Pacific white shrimp Litopenaeus vannamei, cultured in a recirculating system. J Nutri 137: 27632768.

25. Balcázer JL, Rojas-Luna T, Cunningham DP (2007) Effect of the addition of four potential probiotic strains on the survival of pacific white shrimp (Litopenaeus vannamei) following immersion challenge with Vibrio parahaemolyticus. J Invert Pathol 96: 147-150.

26. Gómez GD, Shen MA (2008) Influence of probiotics on the growth and digestive enzyme activity of white Pacific shrimp (Litopenaeus vannamei). J Ocean University of China (English Edition) 7: 215-218.

27. Tseng DY, Ho PL, Huang SY, Cheng SC, Shiu YL, et al. (2009) Enhancement of immunity and disease resistance in the white shrimp, Litopenaeus vannamei, by the probiotic, Bacillus subtilis E20. Fish Shellfish Immunol 26: 339-344.

28. Rengpipat S, Rukpratanporn S, Piyatiratitivorakul S, Menasaveta P (2000) Immunity enhancement in Black tiger shrimp (Penaeus monodon) by a probion bacterium (Bacillus S11). Aquaculture 191: 271-288.

29. Rengpipat S, Tunyanun A, Fast AW, Piyatiratitivorakul S, Menasveta P (2003) Enhanced growth and resistance to Vibrio challenge in pond-reared black tiger shrimp (Penaeus monodon) fed a Bacillus probiotic. Dis Aquat Organ 55: 169173

30. Liu KF, Chiu CH, Shiu YL, Cheng W, Liu CH (2010) Effects of the probiotic, Bacillus subtilis E20, on the survival, development, stress tolerance, and immune status of white shrimp, Litopenaeus vannamei larvae. Fish Shellfish Immunol 28: 837-844.

31. Zhou X, Wang Y, Li W (2009) Effect of probiotic on larvae shrimp (Penaeus vannamei) based on water quality. Aquaculture 287: 349-353.

32. Moriarty DJW (1998) Control of luminous Vibrio species in penaeid aquaculture ponds. Aquaculture 164: 351-358.

33. Brunt J, Newaj-Fyzul A, Austin B (2007) The development of probiotics for the control of multiple bacterial diseases of rainbow trout, Oncorhynchus mykiss (Walbaum). J Fish Dis 30: 573-579.

34. Kumar R, Mukherjee SC, Ranjan R, Nayak SK (2008) Enhanced innate immune parameters in Labeo rohita (Ham.) following oral administration of Bacillus subtilis. Fish Shellfish Immunol 24: 168-172.

35. Newaj-Fyzul A, Adesiyun AA, Mutani A, Ramsubhag A, Brunt J, et al. (2007) Bacillus subtilis $A B 1$ controls Aeromonas infection in rainbow trout (Oncorhynchus mykiss, Walbaum). J Appl Microbiol 103: 1699-1706.

36. Hill JE, Baiano JC, Barnes AC (2009) Isolation of a novel strain of Bacillus pumilus from penaeid shrimp that is inhibitory against marine pathogens. J Fish Dis 32: $1007-1016$

37. Ochoa-Solano JL, Olmos-Soto J (2006) The functional property of Bacillus for shrimp feeds. Food Microbiol 23: 519-525.
38. Naclerio G, Ricca E, Sacco M, Felice MD (1993) Antimicrobial activity of a newly identified bacteriocin of Bacillus cereus. Appl Environ Microbiol 59: 4313-4316.

39. Baumann P, Schubert RHW (1984) Vibrionaceae. In: Krieg, N.A., Holt, J.G. Eds., Bergey's Manual of Systematic Bacteriology vol. 1 William \& Wilkins, Baltimore, pp. 516-549.

40. Ausubel FA, Brent RE, Moore DD, Seidman JG, Smith JA, et al. (1999) Current Protocols in Molecular Biology. 4th ed. New York, John Wiley \& Sons.

41. Hauben L, Moore ER, Vauterin L, Steenackers M, Mergaert J, et al. (1998) Phylogenetic position of phytopathogens within the Enterobacteriaceae. Syst Appl Microbiol 21: 384-397

42. Menasveta P, Fast AW, Piyatiratitivorakul S, Rungsupa S (1991) An improved closed seawater recirculation maturation system for giant tiger prawn (Penaeus monodon Fabricius). Aquacultural Eng 10: 173-181.

43. Watson LP, Mckee AE, Merrell BR (1980) Preparation of microbiological specimens for scanning electron microscopy. Scan Electron Microsc. II: 45-56

44. Strickland JDH, Parsons TR (1972) (2nd Edition) A practical handbook of seawater analysis. J Fish Res Board Canada. 167: 310 pp.

45. Phianphak W, Rengpipat S, Rukpratanporn S, Longyant S, Chaivisuthangkura $\mathrm{P}$, et al. (2005) Production of monoclonal antibodies for detection of Vibrio harveyi. Dis Aquat Organ 63: 161-168.

46. Itami T, Takahashi Y, Tsuchihira E, Igusa H, Kondo M (1994) Enhancement of disease resistance of kuruma prawn Penaeus japonicus and increase in phagocytic activity of prawn hemocytes after oral administration of $\beta$-1,3-glucan (Schizophyllan) In: Chou, L.M., Munro, A.D., Lam, T.J., Chen, T.W.,Cheong L.K.K., et al. Eds., The 3rd Asian Fisheries Forum. Asian Fisheries Society, Manila, Philippines, pp. 375-378

47. Van Harrevald A (1936) A physiological solution for freshwater crustaceans Proc Soc Exp Biol Med 34: 428-432.

48. Adams A (1991) Response of penaeid shrimp to exposure to Vibrio species. Fish Shellfish Immunol 1: 59-70.

49. Statistical Analysis System (1983) SAS Introductory Guide. SAS Institute, Cary, USA, $93 \mathrm{pp}$.

50. Menasveta P, Aranyakanonda P, Rungsupa S, Moree N (1989) Maturation and larviculture of penaeid prawns in closed recirculating seawater systems. Aquacultural Engineering 8: 357-368.

51. Boyd CE (1990) Water quality in ponds for aquaculture. Birmingham Publishing Co., Birmingham, USA.482 pp.

52. U.S. Environmental Protection Agency (1997) Bacillus subtilis Final risk assessment. 2009

53. Council Directive 70/524/EEC. (2004) List of the authorized additives in feeding stuffs published in application of Article 9t (b) of Council Directive 70/524/EEC concerning additives in feedingstuffs. Official J Eur Union C50-C144.

54. Hong HA, Duc LH, Cutting SM (2005) The use of bacterial spore formers asprobiotics. FEMS Microbiol Rev 29: 813-835.

55. Fonseca F, Béal C, Corrieu G (2001) Operating Conditions That Affect the Resistance of Lactic Acid Bacteria to Freezing and Frozen Storage. Cryobiology 43: 189-198.

56. Wang YB, Li JR, Lin, J (2008). Probiotics in aquaculture: Challenges and outlook. Aquaculture 281: 1-4.

57. Rengpipat S, Wongtangprasert N, Palaga T (2009) The use of green fluorescen protein as a marker for monitoring a probiotic Bacillus S11 in the black tige shrimp Penaeus monodon. Aquaculture Nutrition 15: 297-305.

58. Westerdahl A, Olsson J, Kjelleberg S, Conway P (1991) Isolation and characterization of turbot (Scophthalmus maximus) associated bacteria with inhibitory effects against Vibrio anguillarum. Appl Environ Microbiol 57: 22232228

59. Gullian M, Thompson F, Rodriguez J (2004) Selection of probiotic bacteria and study of their immunostimulatory effect in Penaeus vannamei. Aquaculture 233 $1-14$.

60. Ziaei-Nejad S, Rezaei MH, Takami GA, Lovett DL, Mirvaghefi AR, et al. (2006) The effect of Bacillus spp. bacteria used as probiotics on digestive enzyme activity, survival and growth in the Indian white shrimp Fenneropenaeus indicus. Aquaculture 252: 516-524. 
Citation: Utiswannakul P, Sangchai S, Rengpipat S (2011) Enhanced growth of black tiger shrimp Penaeus monodon by dietary supplementation with Bacillus (BP11) as a probiotic. J Aquac Res Development S1:006. doi:10.4172/2155-9546.S1-006

Page 9 of 9

61. Wang YB (2007) Effect of probiotics on growth performance and digestive enzyme activity of the shrimp Penaeus vannamei Aquaculture 269: 259-264.

62. SÖderhäll K, Unestam T (1979) Activation of serum prophenoloxidase in arthropod immunity. The specificity of cell wall glucan activation and activation by purified fungal glycoproteins of crayfish phenoloxidase. Can J Microbiol 25: 406-414

63. SÖderhäll K (1981) Fungal cell wall $\beta-1,3-$ glucans induce clotting and phenoloxidase attachment to foreign surfaces of crayfish hemocyte lysate. Dev Comp Immunol. 5: 565-573.

64. Itami T, Asano M, Tokushige K, Kubono K, Nakagawa A (1998) Enhancement of disease resistance of Kuruma shrimp, Penaeus japonicus, after oral administration of peptidoglycan derived from Bifidobacterium thermophilum. Aquaculture 164: 277-288.

65. Rodríguez J, Espinosa Y, Echeverría F, Cárdenas G, Román R, et al. (2007) Exposure to probiotics and $\beta-1,3 / 1,6$-glucans in larviculture modifies the immune response of Penaeus vannamei juveniles and both the survival to White Spot Syndrome Virus challenge and pond culture. Aquaculture 273: 405415 .

66. Edberg SC (1991) US EPA human health assessment: Bacillus subtilis. Unpublished, US. Environmental Protection Agency, Washington, DC
This article was originally published in a special issue, Probiotic \& Prebiotic Applications in Aquaculture handled by Editor(s). Dr. Daniel L. Merrifield, University of Plymouth, UK; Prof. Zhigang Zhou, Chinese Academy of Agricultural Sciences, China 